Published by Al-Nahrain College of Medicine P-ISSN 1681-6579

E-ISSN 2224-4719

Email: iraqijms@colmed-alnahrain.edu.iq

http://www.colmed-alnahrain.edu.iq

http://www.iraqijms.net

Iraqi JMS 2018; Vol. 16(3)

\title{
Nissl Stain Expression in the Frontal and Parietal Cortices of the Newborn Mice After Prenatal Exposure to Ketamine
}

\author{
Mohanad S. Najm MSc, Hayder J. Mubarak ${ }^{1} P h D$, Hussein A. Jarullah ${ }^{1} P h D$ \\ ${ }^{1}$ Dept. of Human Anatomy, College of Medicine, Al-Nahrain University, Baghdad, Iraq
}

\section{Abstract \\ Background}

Objective

Methods

Results

Conclusion

Keywords Citation
Ketamine is an N-methyl-D-aspartate (NMDA) receptor blocking agent, which is used for induction and maintenance of anesthesia. It affects the cerebral cortex and has an impact on learning and memory functions; suggesting that any changes in NMDA receptors function will have an adverse outcome on learning and memory abilities.

To assess the histological changes in the frontal and parietal cortices of mice offspring's after prenatal exposure to therapeutic doses of ketamine.

Thirty pregnant mice were included in this study. They were divided into two groups named experimental and control groups (15 mice for each group). Those of experimental group were injected intraperitoneally with ketamine in a dose of $50 \mathrm{mg} / \mathrm{kg} /$ day on the $5^{\text {th }}, 10^{\text {th }}, 15^{\text {th }}$ and $20^{\text {th }}$ days of gestational age to showing effect of the ketamine after injection of it in all trimesters of pregnancy, while those of the control group were injected with distal water only with the same volume. The paraffin block sections of frontal and parietal cerebral cortices of newborn mice were stained by nissl stain.

In the control group, the mean number of Nissl stained cells in the frontal cortex showed a statistically significant increase compared to that of parietal cortex, while statistical non-significant decrease in the mean number of nissel stained cells of frontal cortex compared to that of parietal cortex.

latrogenic apoptotic changes were seen in the cerebral cortex of the experimental mice after prenatal exposure to ketamine and it is more considerable in the frontal cortex than the parietal cortex.

Frontal cortex, parietal cortex, ketamine, nissl stain, development

Najm MS, Mubarak HJ, Jarullah HA. Nissl stain expression in the frontal and parietal cortices of the newborn mice after prenatal exposure to ketamine. Iraqi JMS. 2018; 16(3): 268-278. doi: 10.22578/IJMS.16.3.6
List of abbreviations: CNS = Central nervous system, dep = Deep layer, $\mathrm{NIH}=$ National Institute of Health, NMDA $=\mathrm{N}$-methyl-Daspartate, SPSS $=$ Statistical package of social sciences, sup $=$ Superficial layer

\section{Introduction}

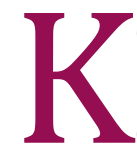
etamine is an $\mathrm{N}$-methyl-D-aspartate (NMDA) receptor blocker (1), it is commonly used for induction and maintenance of anesthesia (2) chiefly in the developing world (3). The NMDA receptors are present in high concentration in the cerebral cortex and play an essential role in learning and memory, and there is evidence suggesting that any changes in NMDA receptor function have an impact on learning and memory abilities ${ }^{(4)}$. The early annotation of ketamine neurotoxicity was of concern, and evidence that the more commonly used anesthetics can produce neuro-degeneration in neonatal animals ${ }^{(5)}$. The cerebral cortex is composed of gray matter and has been estimated to contain 
approximately 10 billion neurons. The cerebral cortex, like gray matter elsewhere in the central nervous system, consists of a mixture of nerve cells, nerve fibers, neuroglia, and blood vessels ${ }^{(6)}$.

The cerebral cortex can be divided into six layers, the cerebral cortex has the following five types of neurons: pyramidal cells, stellate cells, cells of Martinotti, horizontal cells of Cajal and fusiform cells ${ }^{(7)}$.

The cortex contains supporting neuroglial cells (astrocytes), oligodendroglia and microglia (8).

The neuroglial cells function is the mechanical support, metabolic, and protections of neurons collectively form the neuroglia (9).

The trial studies in animals (rats, mice, guinea pigs, piglets, and non-human primates) have shown that exposure of the anesthetic agents during developmental periods can lead to neuronal apoptosis (programmed cell death) or neuronal degeneration (10-14).

The objectives of this study was to assess the histological changes in the frontal and parietal cortices of mice offspring's after prenatal exposure to therapeutic doses of ketamine

\section{Methods}

The animals used in this study were obtained from Laboratory Animal House at College of Medicine, Al-Nahrian University. A total of (30) pregnant females' adult (mus musculus) and aged about (8-12) weeks were used in this study. Weight of the animals was between (20$40 \mathrm{gm})$. After mating, the pregnancy was confirmed the following morning by finding vaginal plug and this was considered as day 0 of gestation (15).

All animals were treated according to National Institute of Health (NIH) Guidelines for the care and use of laboratory animals.

The 30 pregnant mice were divided into two groups; namely the experimental group and the control group (15 mice for each group). The pregnant mice of experimental group were injected intraperitoneally in a single shot with $50 \mathrm{mg} / \mathrm{kg}$ ketamine hydrochloride (16) during ( $5^{\text {th }}$ day, $10^{\text {th }}$ day, $15^{\text {th }}$ day, and $20^{\text {th }}$ day) of pregnancy. The control group was injected intraperitoneally with just distal water during the same gestational days and same volume.

Mice newborn brains were fixed in $10 \%$ formalin, the fixed tissues were then passed for routine paraffin wax embedding process including dehydration, clearing, infiltration, and embedding (17). Sagittal sections of the paraffin blocks, at $5 \mu \mathrm{m}$ thickness, were prepared. Cresyl violet (Nissl) stain was used for examining the neural tissue, were captured by genex camera (5 mega pixels) which was associated built in the microscope.

\section{Results}

Result of nissl stain in frontal cortices of control group

The mean number of cells in the superficial layers (layers I, II and III) of the frontal cerebral cortex was 1598 cells, while the mean number of cells in the deep layers (layers IV, V and VI) of the frontal cerebral cortex was 1360 cells (Figures 1, 2 and 3).

\section{Result of nissl stain in parietal cortices of control group}

The mean number of cells in the superficial layers (layers I, II and III) of the parietal cerebral cortex is 1446 cells, while the mean number of cells in the deep layers (layers IV, $\mathrm{V}$ and $\mathrm{VI}$ ) of the parietal cerebral cortex was 1243 cells (Figures 4, 5 and 6).

\section{The mean number of cells in the frontal and} parietal cerebral cortices

The mean number of total cells (in both superficial and deep layers) of frontal cerebral cortex was 1479 , while that of the parietal cortex was 1334.50. These results showed statistically significant variability $(p$ value $=$ 0.004) (Figure 7).

\section{Result of nissl stain in frontal cortices of experimental group}

The average number of cells in frontal cortices in superficial layers (layers I, II and III) of experimental group is 817 cells, and the number of cells in deep layers (layers IV, V and 
VI) of frontal cortex of experimental group is 701 cells (Figures 8,9 and 10).

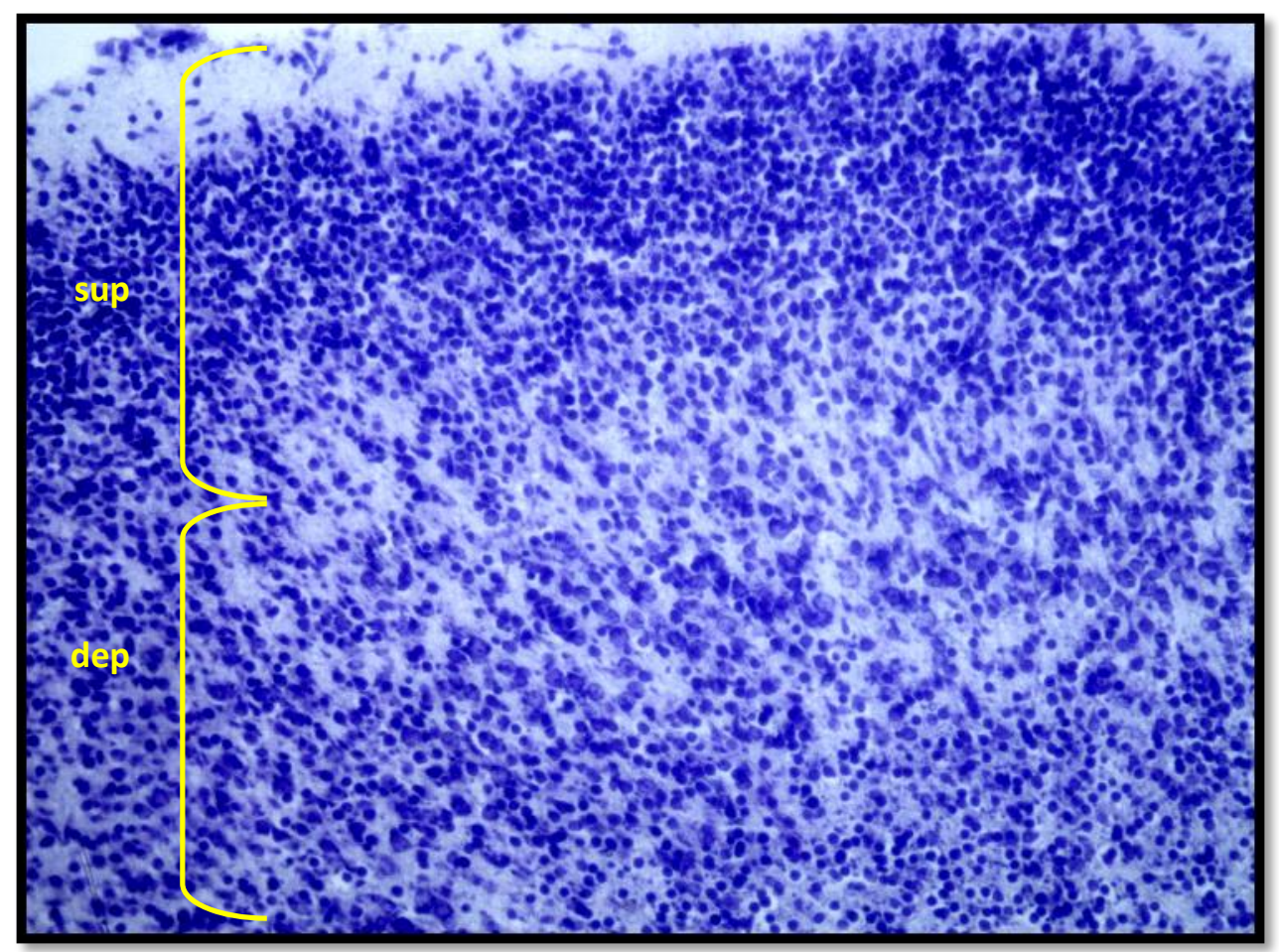

Figure 1. Frontal cortex of control group showing high number of cells on superficial and deep lamina. (sup) superficial layer of cerebral cortex, (dep) Deep layer cerebral cortex. Nissl stain. $\mathrm{X} 200$

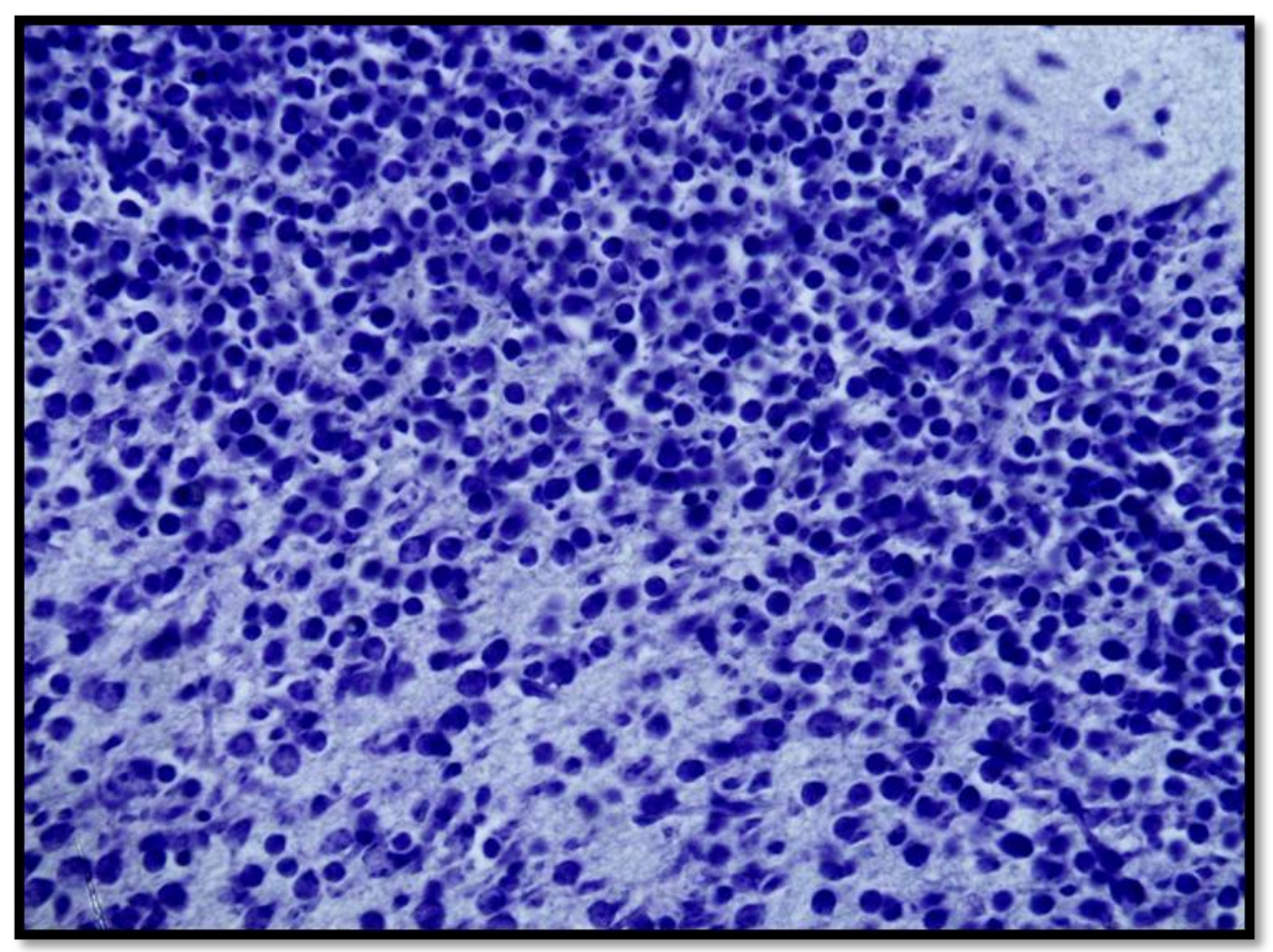

Figure (2): Nissl stain frontal cortex of control group. X400 

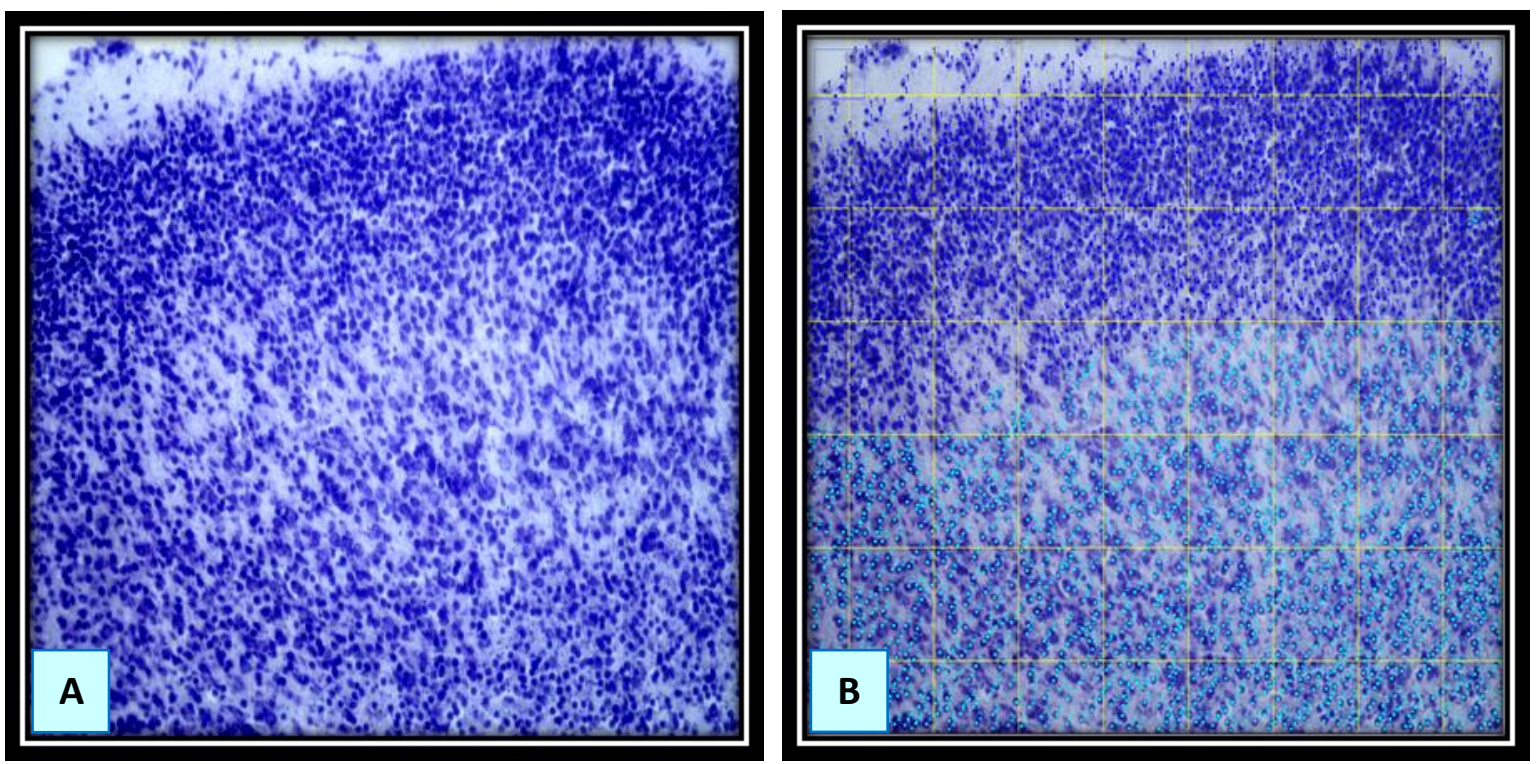

Figure 3. (A) Nissl stain frontal cortex of control group the picture showing shape of cells. X200.

(B) The snap shoot as analyzed by image j program showing divided the picture into regular square and counting number of cells in deep and superficial layer

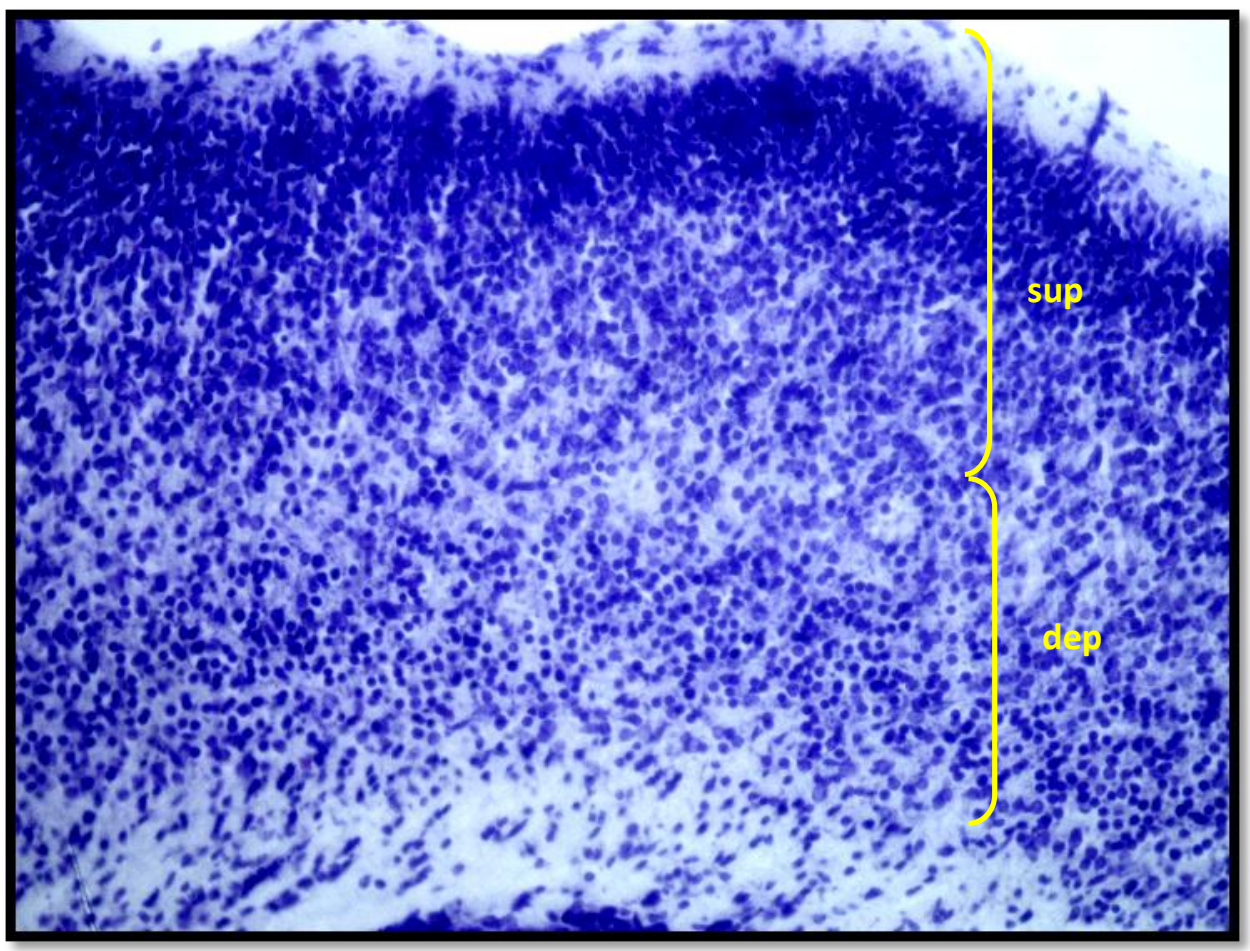

Figure 4. Parietal cortex of control group showing high number of cells on superficial and deep lamina. (sup) superficial layer, (dep) deep layer. Nissl stain. X200 


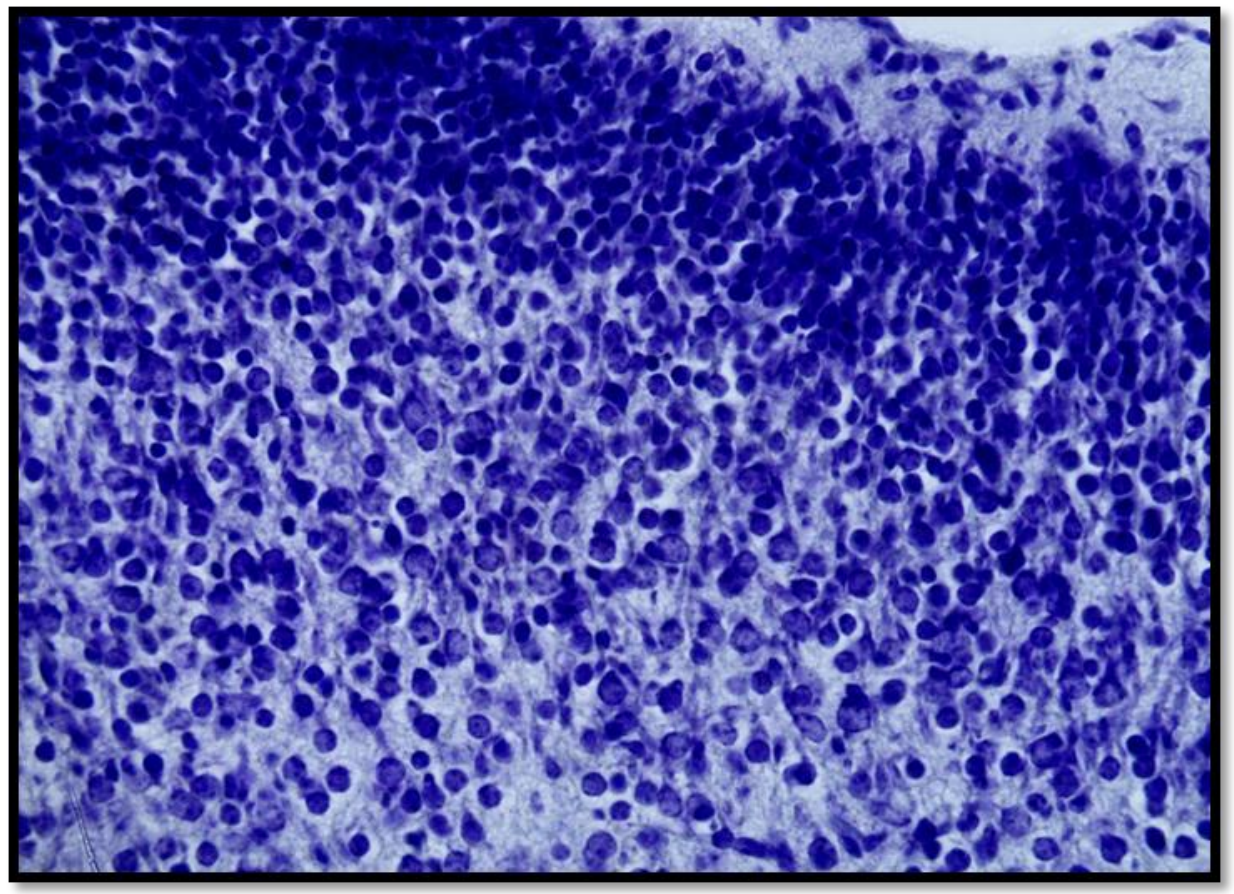

Figure (5): Nissl stain parietal cortex of control group. X400
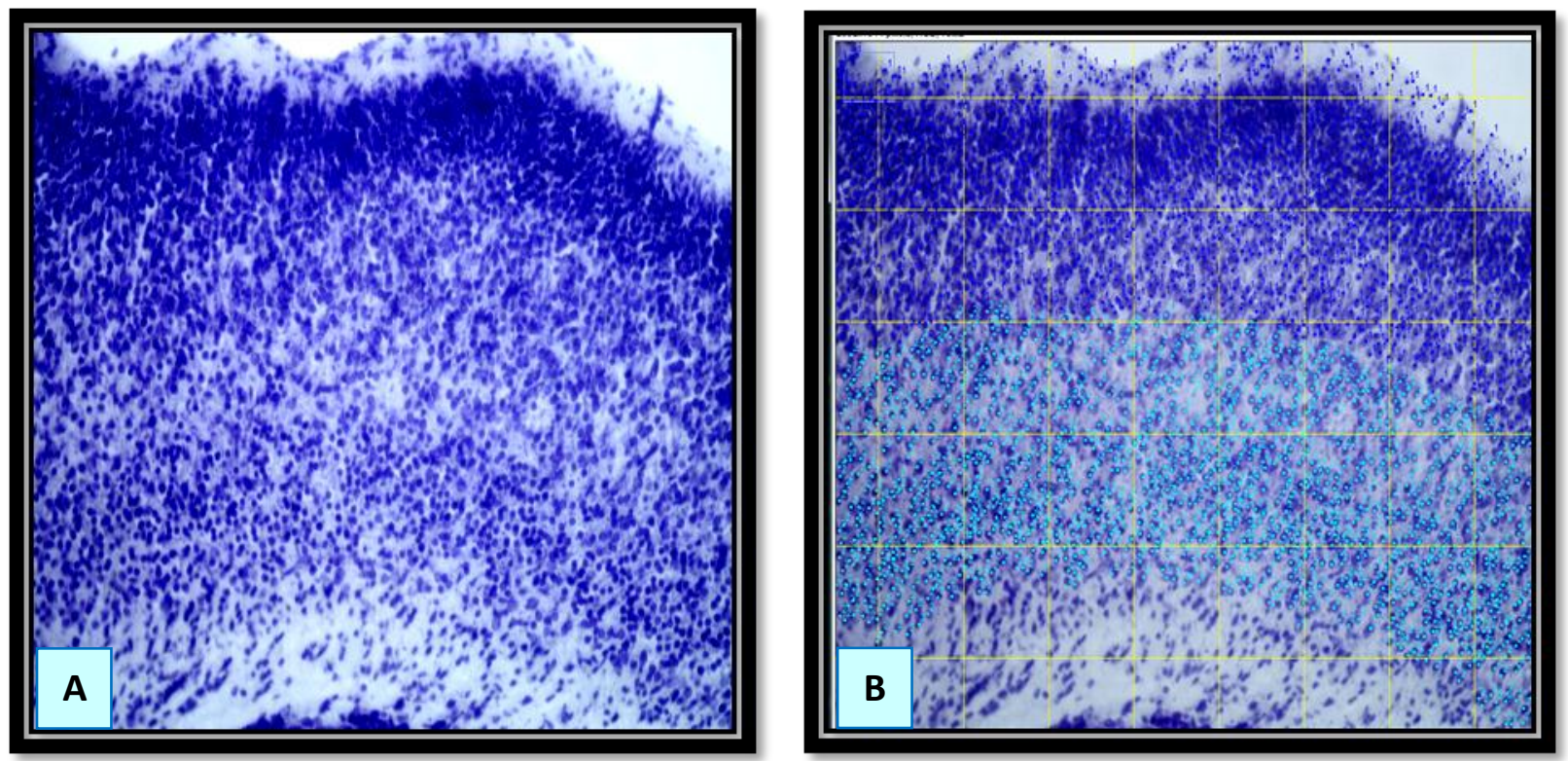

Figure 6. (A) Nissl stain parietal cortex of control group the picture showing shape of cells. X200.

(B) The snap shoot as analyzed by image j program showing divided the picture into regular square and counting number of cells in deep and superficial layer 


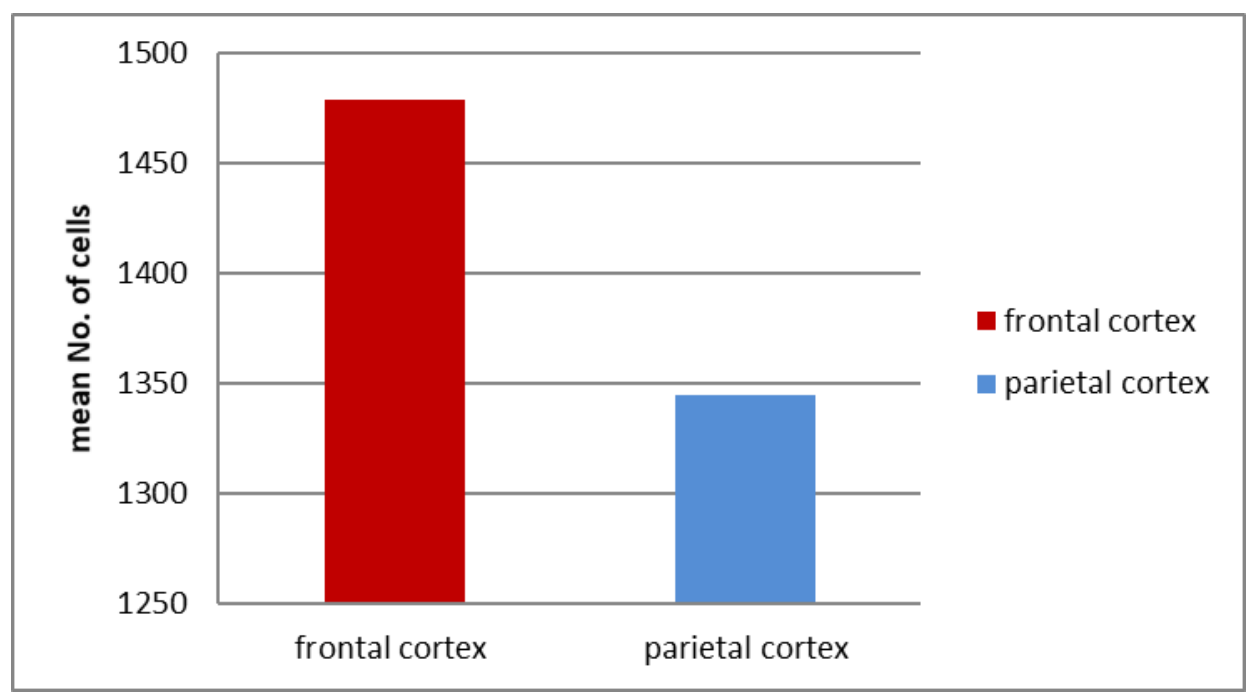

Figure 7. The values of number of cells obtained from frontal and parietal cortices in newborn mice in the control groups

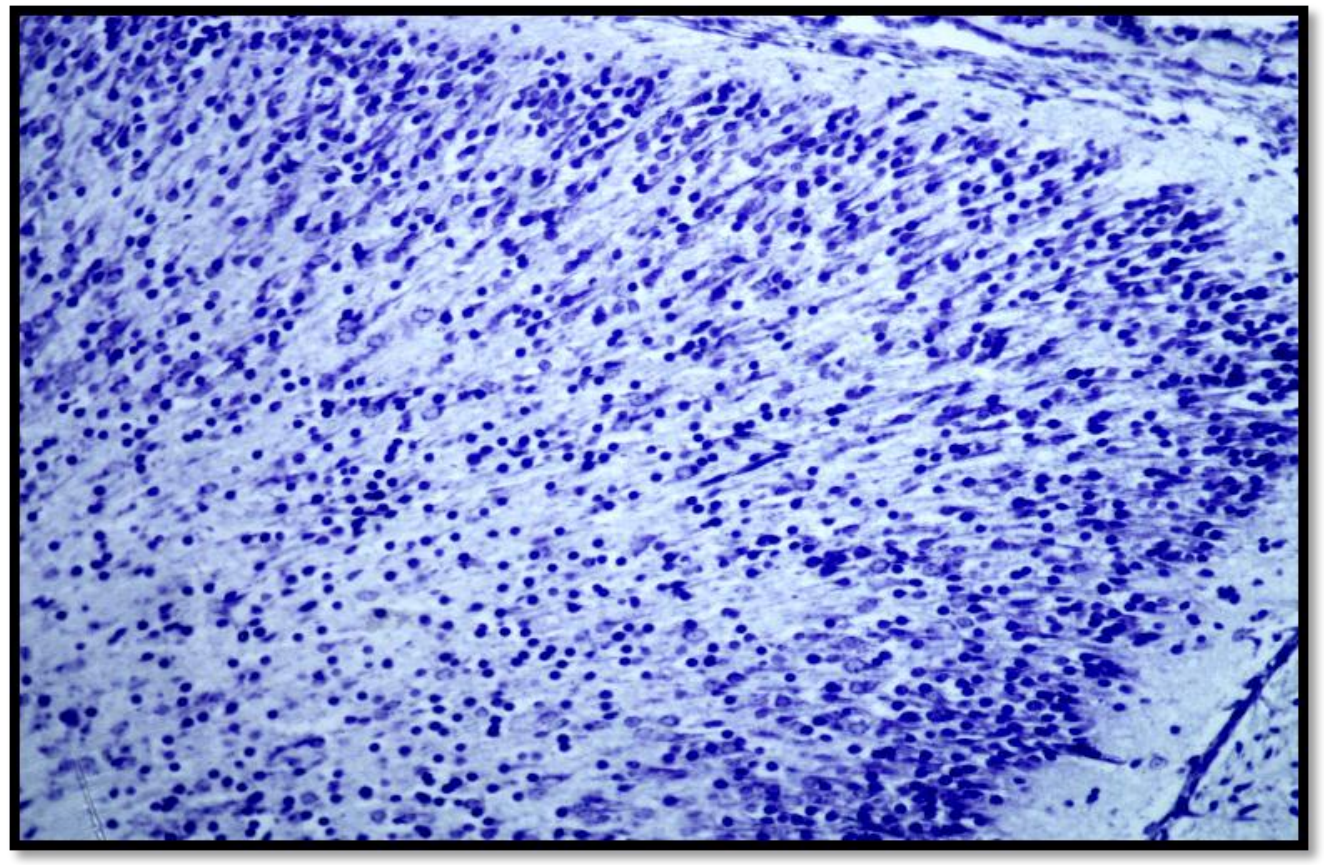

Figure 8. Frontal cortex of experimental group. Showing low number of cells on superficial and deep lamina when compare to control group. Nissl stain. X200 


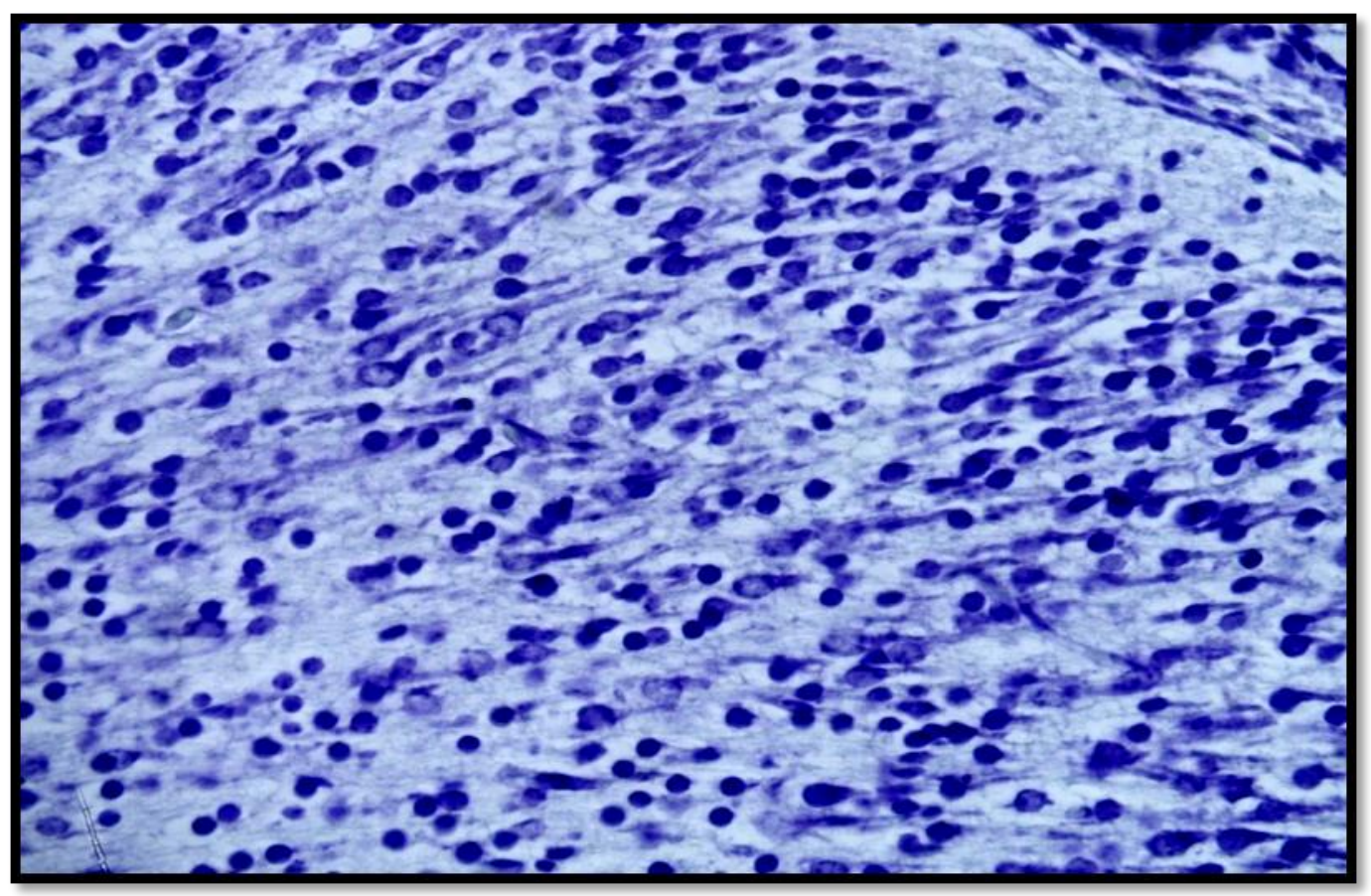

Figure 9. Frontal cortex of experimental group. Showing low number of cells on superficial and deep lamina when compare to control group. Nissl stain. X400
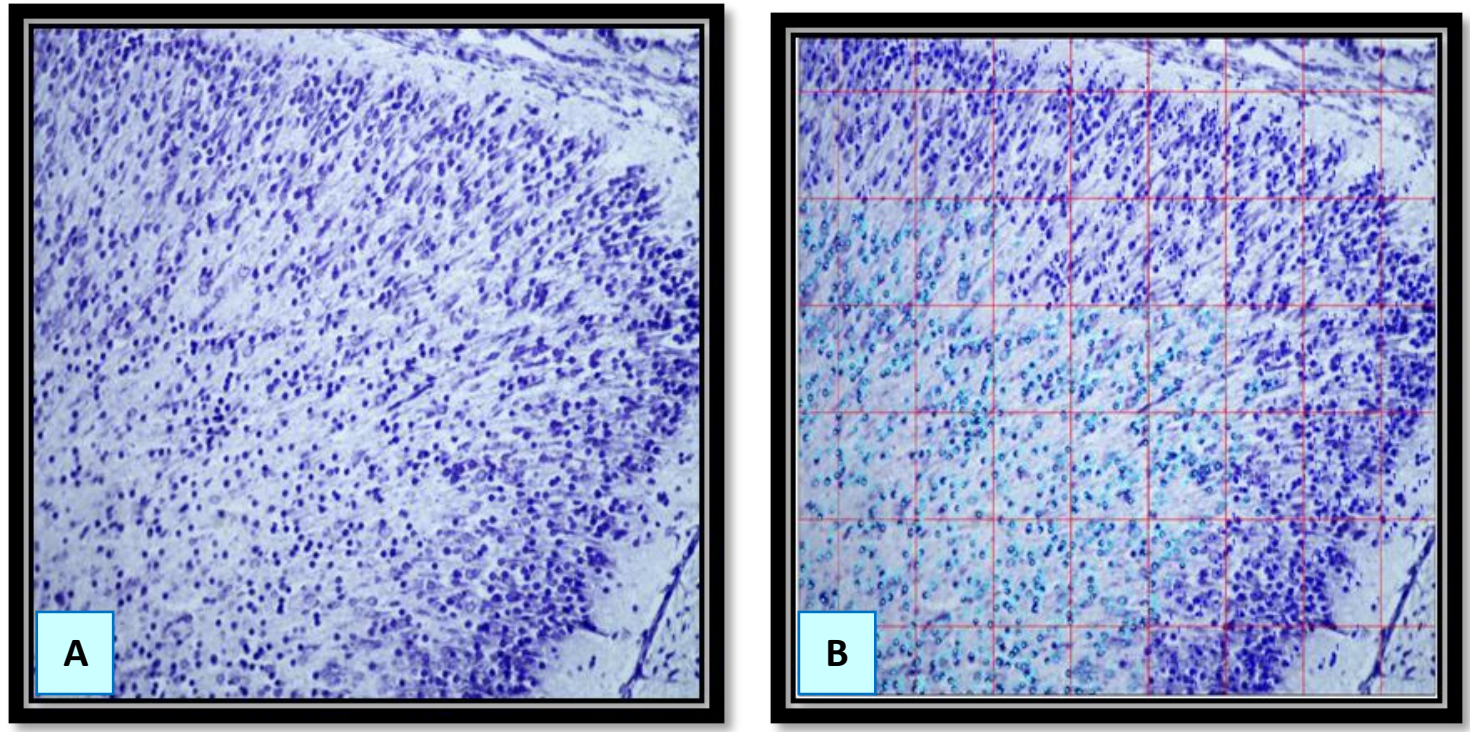

Figure 10. (A) Nissl stain parietal cortex of control group the picture showing shape of cells. X200. (B) The snap shoot as analyzed by image j program showing divided the picture into regular square and counting number of cells in deep and superficial layer 
Result of nissl stain in parietal cortices of experimental group

The number of cells in parietal cortices in superficial layers (layers I, II and III) of experimental group is 853 cells, and the number of cells in deep layers (layers IV, V and $\mathrm{VI})$ of parietal cortex of experimental group is 728 cells (Figures 11, 12, 13).

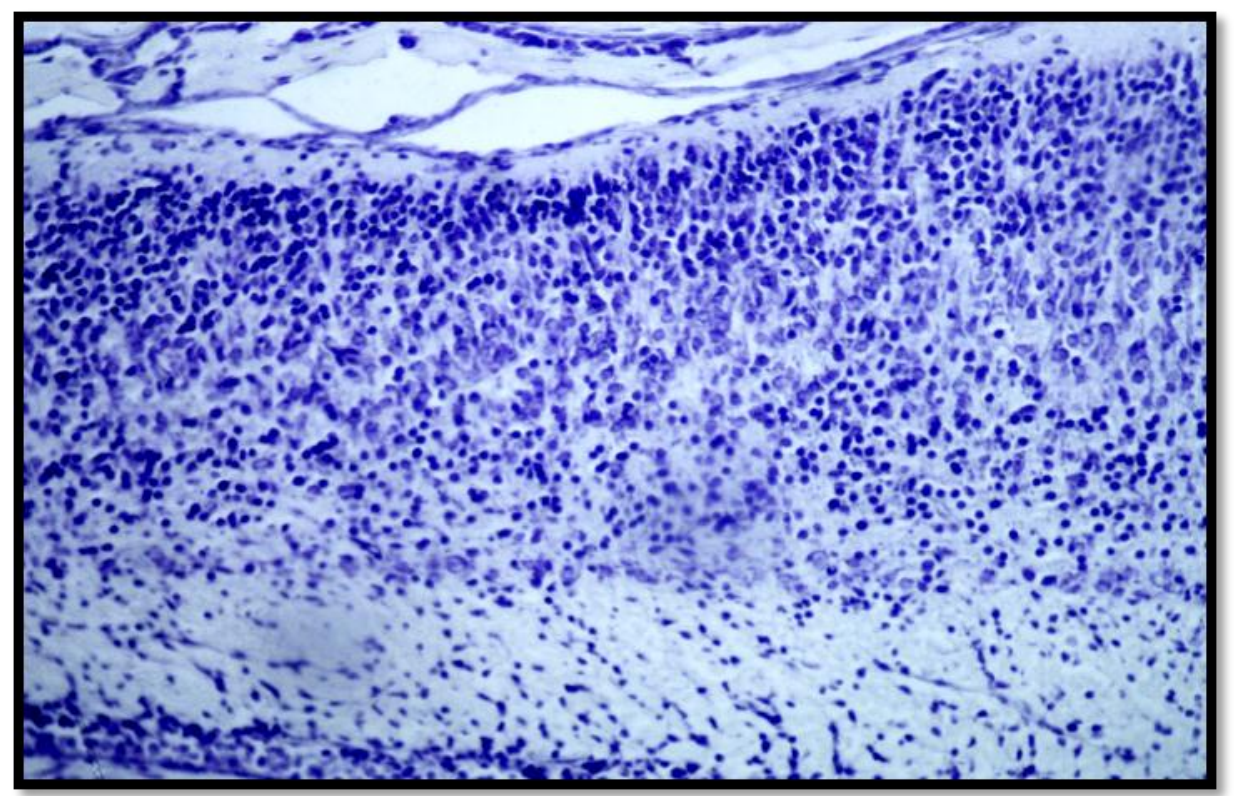

Figure 11. Parietal cortex of experimental group. Showing low number of cells on superficial and deep lamina when compare to control group. Nissl stain X200

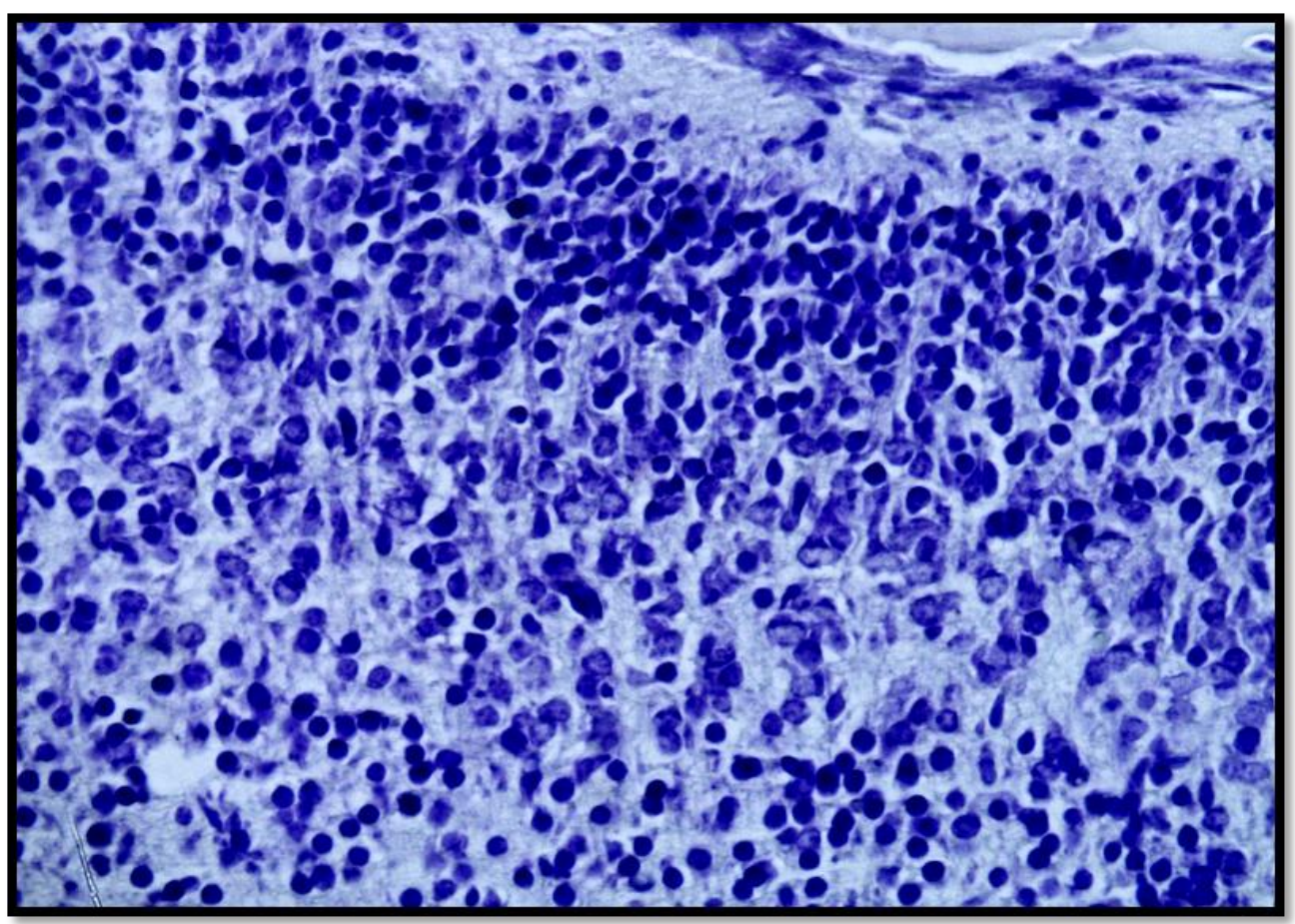

Figure 12. Parietal cortex of experimental group. Showing low number of cells on superficial and deep lamina when compare to control group. Nissl stain X400 

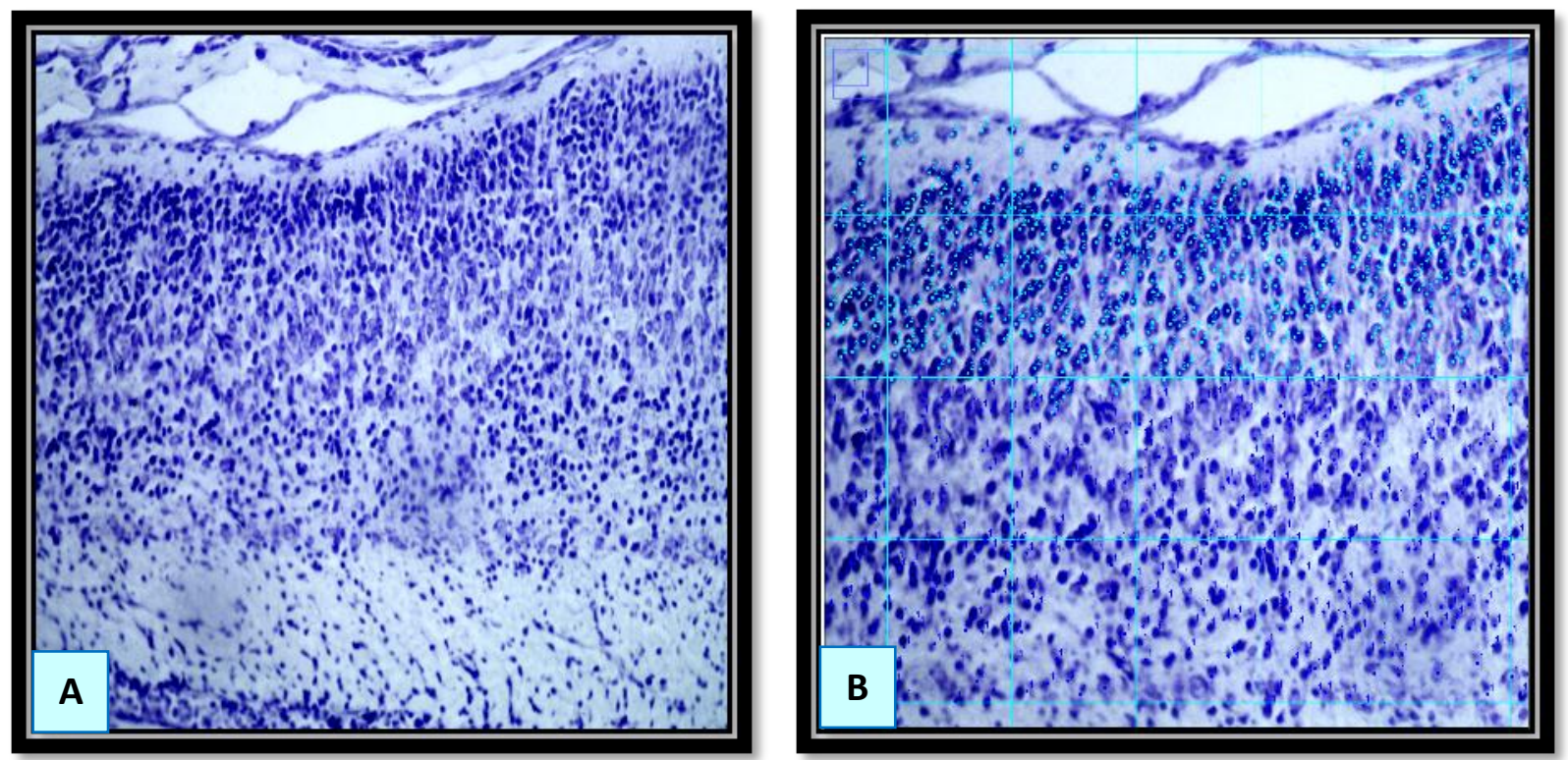

Figure 13. (A) Nissl stain parietal cortex of experimental group the picture showing shape of cells. X200. (B) The snap shoot as analyzed by image j program showing divided the picture into regular square and counting number of cells in deep and superficial layer

The comparison between frontal and parietal in experimental groups

The statistical analysis of the number of cells in frontal and parietal cortices in the experimental group showed non- significant variability, and the ( $p$ values $=0.195)$ for the frontal and parietal cortices in experimental group, as the mean of frontal cortex was 759.00, while the mean number of parietal cortex was 790.50 (Figure 14).

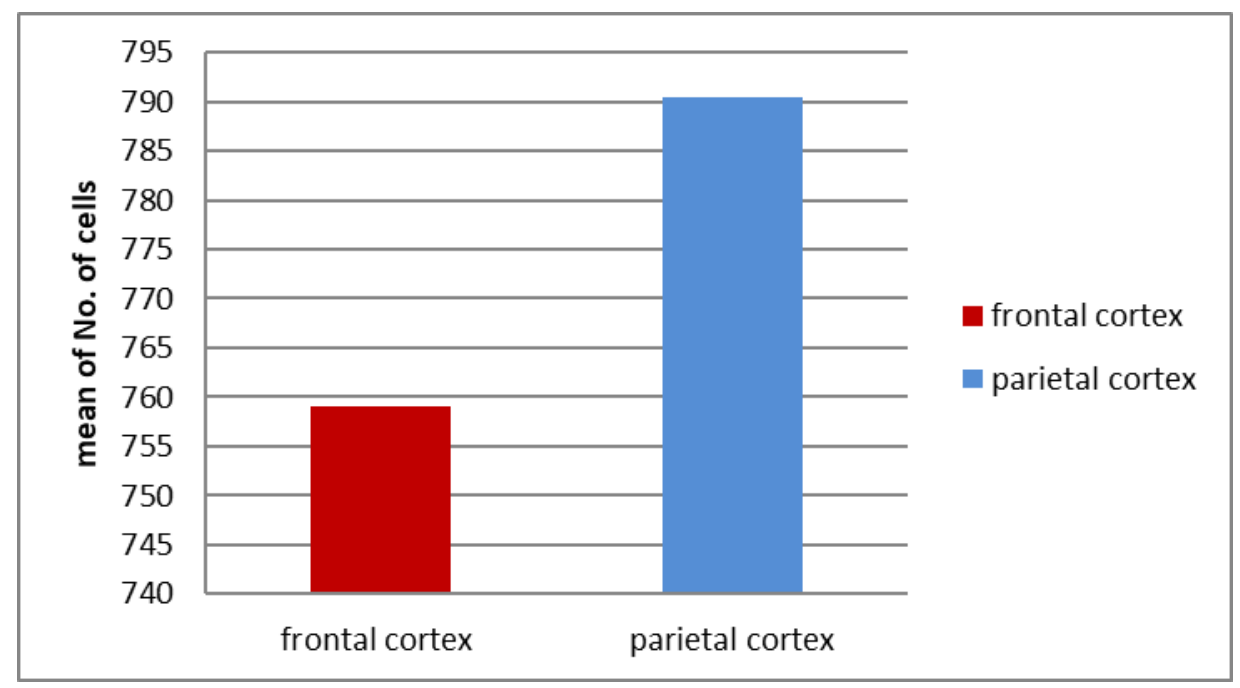

Figure 14. The values of number of cells obtained from frontal and parietal cortices in newborn mice in the experimental groups 


\section{Discussion}

It was reported that quantitative neuroanatomical studies lack detailed cytological descriptions of neurons and glial cell types especially in the primate brain, the evaluation of the cellular density (both neurons and glial cells) done in the cerebral cortices of the animals involved in this study is experiment to elaborate the quantitative neuroanatomical aspect of histological changed resulting after prenatal ketamine exposure, this classical Nissl's staining technique had been used in this study because it labels all cells in the brain in distinct ways ${ }^{(18)}$. The procedure to compare the percentage of cell number in the deeper lamina (IV, V and VI) with that in the superficial lamina (I, II and III) had been submitted in accordance to the followings:

First, laminar structure of cerebral cortex is determined during early development in which, post mitotic cells migrate out to form cortical laminae in an inside-out manner in which the deeper cortical layers are formed before the more superficial ones ${ }^{(19)}$.

Second, Ketamine leads to marked apoptotic changed in the period of peak synaptogenesis (20). This fact had also been considered in the appraisal of comparing the percentage of cells in deep and superficial lamina in congruence to reports that neurons completing their migration showed synaptogenesis earlier in deeper layers than in more superficial ones ${ }^{(21)}$. These findings agreed with the report that cellular density in the brain coincides with neurological pathologies as well as with changes in brain associated with pharmacological treatment (22).

Nevertheless, are different techniques used previously to count the number of neurons in the cerebral cortex ${ }^{(23)}$.

This study concluded that iatrogenic apoptotic changes were seen in the cerebral cortex of the experimental mice after prenatal exposure to ketamine and it is more considerable in the frontal cortex than the parietal cortex.

\section{Acknowledgments}

Regard and gratefulness should be presented to the staff members Department of Human Anatomy at the College of Medicine, Al-
Nahrain University for their assistance and cooperation.

\section{Authors contribution}

Dr. Najm: The MSc candidate performing the laboratory research work. Dr. Mubarak: The advisor of the research performing the interpretation of the results. Dr. Jarullah: Analysis data of the result.

\section{Conflict of interest}

The authors disclose no any financial and personal relationships with other people or organizations that inappropriately influence (bias) our work.

\section{Funding}

The research working funding was provided by the authors.

\section{References}

1. Wang C, Sadovova N, Hotchkiss C, et al. Blockade of $\mathrm{N}$-methyl-D-aspartate receptors by ketamine produces loss of postnatal day 3 monkey frontal cortical neurons in culture. Toxicol Sci. 2006; 91(1): 192-201. doi: 10.1093/toxsci/kfj144

2. Chan $W H$, Sun WZ, Ueng $T H$. Induction of rat hepatic cytochrome $\mathrm{P}-450$ by ketamine and its toxicological implications. J Toxicol Environ Health A. 2005; 68(1718): 1581-97. doi: 10.1080/15287390590967522.

3. Craven R. Ketamine. Anaesthesia. 2007; 62(s1): 4853. doi: 10.1111/j.1365-2044.2007.05298.x.

4. Magnusson KR, Brim BL, Das SR. Selective vulnerabilities of $\mathrm{N}$-methyl-D-aspartate (NMDA) receptors during brain aging. Front Aging Neurosci. 2010; 2: 11. doi: 10.3389/fnagi.2010.00011.

5. Hudson A, Hemmings $\mathrm{HC}$ Jr. Are anaesthetics toxic to the brain? Br J Anaesth. 2011; 107(1): 30-7. doi: 10.1093/bja/aer122.

6. Snell R. Clinical neuroanatomy. 7th ed. Philadelphia: Lippincott Williams \& Wilkins; 2010.

7. Kumar V, Abbas AK, Aster JC. Robbins \& Cotran Pathologic basis of disease. 8th ed. New York: Saunders; 2010. p. 1313-9.

8. Young B, O'Dowd G, Woodford P. Wheater's Functional histology a text and color atlas. 6th ed. USA: Churchill Livingstone; 2014.

9. Mescher AL. Junqueira's Basic histology, text and atlas. 13th ed. USA: McGraw-Hill Education; 2013.

10. Head B, Patel H, Niesman IR, et al. Inhibition of p75 neurotrophin receptor attenuates isofluranemediated neuronal apoptosis in the neonatal central nervous system. Anesthesiology. 2009; 110(4): 81325. doi: 10.1097/ALN.0b013e31819b602b. 
11. Istaphanous GK, Loepke AW. General anesthetics and the developing brain. Curr Opin Anaesthesiol. 2009; 22(3): 368-73.

12. Jevtovic-Todorovic $V$, Hartman RE, Izumi $Y$, et al. Early exposure to common anesthetic agents causes widespread neurodegeneration in the developing rat brain and persistent learning deficits. J Neurosci. 2003; 23(3): 876-82.

13. Mellon RD, Simone AF, Rappaport BA. Use of anesthetic agents in neonates and young children. Anesth Analg. 2007; 104(3): 509-20. doi: 10.1213/01.ane.0000255729.96438.b0.

14. Sun L. Early childhood general anaesthesia exposure and neurocognitive development. Br J Anaesth. 2010; 105 Suppl 1: i61-8. doi: 10.1093/bja/aeq302.

15. Suckow MA, Danneman P, Brayton C. The laboratory mouse. Boca Raton: CRC Press Inc.; 2001.

16. Hahn N, Eisen RJ, Eisen L, et al. Ketaminemedetomidine anesthesia with atipamezole reversal: practical anesthesia for rodents under field conditions. Lab Anim (NY). 2005; 34(2):48-51. doi: 10.1038/laban0205-48.

17. Bancroft J, Suvarna S, Layton C. Bancroft's theory and practice of histological techniques. $7^{\text {th }}$ ed. China: Churchill living stone; 2013.

18. García-Cabezas MÁ, John YJ, Barbas $H$, et al. Distinction of neurons, glia and endothelial cells in the cerebral cortex: an algorithm based on cytological features. Front Neuroanat. 2016; 10: 107. doi: 10.3389/fnana.2016.00107.

19. Kornack DR, Rakic P. Radial and horizontal deployment of clonally related cells in the primate neocortex: relationship to distinct mitotic lineages. Neuron. 1995; 15(2): 311-21.

20. Arends MJ, Morris RG, Wyllie AH. Apoptosis the role of endonuclease. Am J Pathol. 1990; 136(3): 593-608.

21. Huttenlocher PR. Morphometric study of human cerebral cortex development. Neuropsychologia. 1990; 28(6): 517-27.

22. Kołodziejczyk A, Ładniak $M$, Piórkowski A. Constructing software for analysis of neuron, glial and endothelial cell numbers and density in histological Nissl-stained rodent brain tissue. J Med Inform Technol. 2014; 23. 77-86.

23. Meyer HS, Wimmer VC, Oberlaender $M$, et al. Number and laminar distribution of neurons in a thalamocortical projection column of rat vibrissal cortex. Cereb Cortex. 2010; (10): 2277-86. doi: 10.1093/cercor/bhq067.

Correspondence to Mohanad S. Najm

E-mail: mohanad.suhail@yahoo.com

Received Oct. $8^{\text {th }} 2017$

Accepted Apr. 30 2018 